\title{
Microbial and Mineral Composition of Fortified Fermented Local Meal from Pigeon Pea (CAJANUS CAJAN) and Unripe Plantain
}

\author{
Odion-Owase, E, Oladebeye, A. A. and Olukoya, F. O. \\ Department of Food Technology, Auchi Polytechnic, Auchi
}

\begin{abstract}
A fortified fermented local meal was produced from pigeon pea and unripe plantain. $50 \mathrm{~kg}$ of pigeon pea was subjected to solid state method of fermentation for $72 \mathrm{hrs}$. Samples of meal were produced from fermented pigeon pea and unripe plantain at different ratios and labeled samples A, B and C. Sample A had 10\% fermented pigeon pea and $90 \%$ unripe plantain flour, sample B had $20 \%$ fermented pigeon pea and $80 \%$ unripe plantain flour while sample $\mathrm{C}$ had $30 \%$ fermented pigeon pea and $70 \%$ unripe plantain flour. The three samples were subjected to microbial and mineral analysis. Lactobacillus plantarum and Saccharomyces cerevisae were isolated from all the samples. The microbial count ranged from $1.2 \times 106 \mathrm{CfU} / \mathrm{g}$ to $1.8 \times 106 \mathrm{CfU} / \mathrm{g}$ which was not significant. There was no significant difference $(p \leq 0.05)$ in the microbial count of the three samples. Mineral analysis revealed that the samples were rich in sodium, potassium, calcium, iron and phosphorus. However, sample $\mathrm{C}$ had the highest sodium, potassium, calcium and phosphorus while sample A had the highest iron value. Sample A had the least value of sodium, potassium, calcium and phosphorus.
\end{abstract}

Keywords: Microbial, Mineral, Fermentation, Pigeon Pea and Plantain.

DOI: $10.7176 / \mathrm{FSQM} / 111-02$

Publication date:October $31^{\text {st }} 2021$

\section{Introduction}

Pigeon pea (Cajanus cajan) is a legume crop grown in the tropics and widely consumed in Africa, India and the Caribbean. It contains about $19.6 \%$ protein (Okpala and Mamah, 2001) and therefore serves as an important source of vegetable protein. Pigeon pea contains $20-22 \%$ protein, $1.2 \%$ fat, $65 \%$ carbohydrate and $3.8 \%$ ash (Onweluzo and Nwabugwu, 2009) high levels of cysteine, methionine and lysine (Osagie, 1998) and smaller amount of oligosaccharides (Singh, 1988).

Processing techniques such as boiling, roasting and germination are means of improving the nutritional value of food (Nergiz and Gokgoz, 2007). Fermentation is defined as a bio-processing using microorganisms and their enzymes to achieve desirable quality characteristics of food products (Singhanai, 2009). The origin of fermented foods goes back to thousands of years. It is one of the oldest ways of food processing. According to (Lawal, et. al, 2009), fermentation improves food digestibility and nutritional quality.

Plantain (Musa paradisiacal) belongs to the genus Musa in the family of Musaceae. It is a giant perennial herb and cultivated in the many tropic and subtropical countries of the world. It ranks third after yam and cassava for sustainability in Nigeria. It is used as a source of starchy staple food for millions of people in Nigeria. Mature plantain pulp is rich in iron, potassium and vitamin A but low in protein and fat.

\section{Objectives of this Research}

- To produce fortified fermented local meal from pigeon pea and unripe plantain.

- To determine the microbial quality of the fortified fermented local meal from pigeon pea and unripe plantain.

- To determine the mineral composition of the fortified fermented local meal from pigeon pea and unripe plantain.

- To produce meals of high nutritional value to solve the problem of malnutrition particularly in children.

\section{Materials and Methods}

- Sample Collection: Pigeon pea and unripe plantain used for this research were purchased from Jattu market in Auchi, Edo state, Nigeria. The raw materials were transported to food processing workshop in the department of food Technology, Auchi Polytechnic, Auchi.

- Sample Processing Prior to Use: The pigeon peas were sorted to remove dirt's, broken one and extraneous materials which may serve as contaminants. The pigeon peas were washed with portable water treated with $5 \%$ sodium metabisulphite and drained. It was then dried in hot air oven at $50 \mathrm{C}$ for 24 hours. The unripe plantain was sliced, washed and treated with 5\% sodium meta bisulphate and drained. It was then dried in hot air oven at $50 \mathrm{C}$ for 72 hours. $50 \mathrm{~kg}$ of the unripe plantain was then grinded into powder. Sample A had 10\% fermented pigeon pea and $90 \%$ unripe plantain. Sample B had $20 \%$ fermented pigeon pea and $80 \%$ unripe plantain, while sample C had $30 \%$ fermented pigeon pea 
and $70 \%$ unripe plantain. $200 \mathrm{~g}$ of dried crayfish was added to $1 \mathrm{~kg}$ of each sample. The products were well packaged.

- Microbiological Analysis: Isolation and identification of microorganisms were carried out from the method of (Fawole and Oso, 2007).

- Determination of Mineral Contents: The mineral composition of the samples were determined by ashing method, followed by reading of the level of mineral (AOAC, 2016).

- Statistical Analysis: All experiments were carried out in triplicates. Results obtained were analyzed by one way analysis of variance (ANOVA) and Dunca's multiple range tests was used to separate means using statistical package for the social sciences (SPSS) version 16 while $\mathrm{P} \leq 0.05$ was accepted as significant level.

\section{Results}

Table I: Isolated microorganisms from fermented meal

\begin{tabular}{|l|l|}
\hline Sample & Isolated Microorganisms \\
\hline A & $\begin{array}{l}\text { Lactobacillus plantarum } \\
\text { Saccharomyces cerevisae }\end{array}$ \\
\hline B & $\begin{array}{l}\text { Lactobacillus plantarum } \\
\text { Saccharomyces cerevisae }\end{array}$ \\
\hline C & $\begin{array}{l}\text { Lactobacillus plantarum } \\
\text { Saccharomyces cerevisae }\end{array}$ \\
\hline
\end{tabular}

Table II: Microbial counts from fermented meal

\begin{tabular}{|l|l|l|}
\hline Sample & $\begin{array}{l}\text { Bacterial counts } \\
\text { (CfU/g) }\end{array}$ & $\begin{array}{l}\text { Fungi counts } \\
\text { (SfU/g) }\end{array}$ \\
\hline $\mathrm{A}$ & $1.2^{\mathrm{a}} \times 10^{6} \pm 0.05$ & $1.1^{\mathrm{a}} \times 10^{6} \pm 0.02$ \\
\hline $\mathrm{B}$ & $1.8^{\mathrm{b}} \times 10^{6} \pm 0.01$ & $0.8^{\mathrm{b}} \times 10^{6} \pm 0.01$ \\
\hline $\mathrm{C}$ & $1.8^{\mathrm{c}} \times 10^{6} \pm 0.05$ & $1.4^{\mathrm{c}} \times 10^{6} \pm 0.02$ \\
\hline
\end{tabular}

Means with the same superscripts down the Column are not significantly different $(\mathrm{p} \leq 0.05)$

\section{Note:}

Sample $A=10 \%$ fermented pigeon pea and $90 \%$ unripe plantain

Sample B $=20 \%$ fermented pigeon pea and $80 \%$ unripe plantain

Sample c $=30 \%$ fermented pigeon pea and $70 \%$ unripe plantain

Table III: Mineral composition of fermented meal

\begin{tabular}{|l|l|l|l|l|l|}
\hline Sample & Na (Mg) & Ca $(\mathbf{M g})$ & K $(\mathbf{M g})$ & P (Mg) & Fe(Mg) \\
\hline A & $17.32^{\mathrm{a}} \pm 0.02$ & $22.14^{\mathrm{ab}} \pm 0.01$ & $64.23^{\mathrm{bd}} \pm 0.05$ & $14.16^{\mathrm{dc}} \pm 0.01$ & $0.98^{\mathrm{e}} \pm 0.02$ \\
\hline B & $25.21^{\mathrm{b}} \pm 0.02$ & $34.26^{\mathrm{ac}} \pm 0.02$ & $78.14^{\mathrm{cd}} \pm 0.05$ & $15.23^{\mathrm{db}} \pm 0.01$ & $0.72^{\mathrm{ed}_{ \pm}} \pm 0.01$ \\
\hline C & $38.13^{\mathrm{c}} \pm 0.02$ & $40.16^{\mathrm{ad}} \pm 0.02$ & $91.83^{\mathrm{d}} \pm 0.05$ & $18.36^{\mathrm{de}} \pm 0.01$ & $0.31^{\mathrm{f}} \pm 0.02$ \\
\hline
\end{tabular}

Means with the same superscripts along the row are not significantly different $(\mathrm{p} \leq 0.05)$

\section{Note:}

Sample $A=10 \%$ fermented pigeon pea and $90 \%$ unripe plantain

Sample B $=20 \%$ fermented pigeon pea and $80 \%$ unripe plantain

Sample C $=30 \%$ fermented pigeon pea and $70 \%$ unripe plantain

\section{Discussion}

Fermentation as method of food processing helps in conversion of sugar and other carbohydrates into organic acids, enrichment of diet through development of a diversity of flavour, aroma and texture of food substrates, preservation of substantial amount of food through lactic acid, alcohol, acetic acid and alkaline fermentation, biological enrichment of food substrates with protein essential amino acids, elimination of anti-nutrients and decrease in cooking time (Onwuka, 2014).

The microorganisms isolated and identified from the formulated meal were Lactobacillus plantarum and Saccharomyces cerevisae. These microorganisms have been found to be responsible for fermentation of most legumes and cereals (Tucker, 2003). These microorganisms have also been isolated in various investigations of fermented products such as alcoholic beverages and Fufu (Ogbona, et al., 1998). Lactobacillus plantarum isolated from the formulated meal belongs to the group of lactic acid bacteria which are responsible for fermented process because of their unique metabolic characteristics (Wakil, et al., 2014) the low microbial load of the formulated meal can be attributed to the production of lactic acid, thereby reducing the phipathogenic microorganisms were not isolated. The isolated microorganisms are beneficial to humans. 
Potassium was the most abundant mineral in the formulated meal while iron was the least mineral obtained. Potassium and sodium are important in maintaining the normal water balance, conservation of osmosis and acid balance, potassium is necessary for the metabolism of carbohydrates and proteins. It also protects the internal anterior walls against any damages, prevents hemorrhages' and brain/heart attack (Oladele, et al., 2009). Calcium is also very essential for bone development.

\section{Conclusion}

The formulated, fortified and fermented pigeon pea and unripe plantain local meal produced did not contain pathogenic microorganisms but contained microorganisms that are beneficial to humans. The formulated meal was also rich in minerals.

\section{Recommendation}

The formulated meal produced can serve as composite flour which can be used for domestic purpose. It can also be used as weaning food to solve the problem of malnutrition in children.

\section{Acknowledgement}

The authors are thankful to TETFUND for providing this institutional based Research (IBR) grant to facilitating this research. This indeed has given us the opportunity to contribute our quota to the nation building in terms of food production and development.

\section{References}

AOAC, (2016). Official method of analysis. Association of official analytical chemists. $22^{\text {nd }}$ edition. Washington DC. PP. $35-60$

Fawole, M. O. \& Oso, B. A. (2004). Characterization of bacteria: Laboratory Manual of Microbiology. $3^{\text {rd }}$ Edition. Spectrum Book Limited, Ibadan. Nigeria PP $24-26$

Lawal, A. K.; Oyedoyin, .O.B and Olatunji, .O. (2009). Fate of Pathogenic bacteria during the fermentation of cereal porridge (Ogi). A wearing Food formula. Nigerian Food Journal 27 (1) 19 - 24

Nergiz, C. \& Gokgoz, M. (2007). Effects of traditional cooking methods on some ant nutrients and invitro protein digestibility of vean varieties (Phaseolus vulgancies ) grown in Turkey. International Journal Of Food Science. Tech : 42 (7) 868-873

Ogbona, C .L.C.; Akuesh, C.O. \& Yilzung, I.D. (1998). Studies on some Nigerian indigenous alcohol Beverages. A laboratory production of Burukutu. Nigerian Journal of Biotechnology 1:103-120

Okpala, L.C. \& Mamah, E.N. (2001). Functional properties of raw and processed pigeon peas (Cajanus cajan) flour. International Journal of Food Sciences and Nutrition (52) 343-346

Oladele, K. A.; Osundahiensi, F. O. \& Adebowale, A.Y. (2009). Influence of processing techniques on the nutrients and anti-nutrients of tiger nut (Cyperus esculentus .L). World Journal Dairy and Food Science 2.88-93

Onweluzo, J.C. \& Nwabugwu, C.C. (2009). Nutrient and anti-nutrient composition of condiments produced from some fermented underutilized legumes. Journal of Food Biochemistry 30 (5) 576-588

Onwuka, G.I. (2014). Food science and Technology. $1^{\text {st }}$ edition Naphali press. 22 market street, Somolu Lagos Nigeria PP. 695-696.

Osagie, A.U (1998). Anti nutritional factors in AU Osagie .O U Eked (ed). Nutritional Quality of Plant Foods PP -53-83. Published by post Harvest Research unit department of biochemistry.University of Benin Nigeria.

Singh, U. (1988). Anti-nutritional factors of chickpea and pigeon pea and their removal by processing plants foods. Human Nutrition 35, 339-35

Singhania, R.R.; Patel A. K.; Soccol, C. R. \& Pardey, A. (2209) Recent advanced in solid state fermentation in biochemistry. English Journal Vol .44 (1) 13-18

Tucker, S.C. (2003) Floral development in legumes. Journal of Plant Physiology 13N 911-926

Wakil, S. M. A.; Ayenuro, O. T. \& Oyinlola, K. A. (2014). Microbiological and nutritional Assessment of sarter developed fermented tiger nut milk. Food and Nutrition Sciences 5: 49-506. 